\title{
$\mathbf{P} 1100$
}

\section{一企業における自己宣言型健康づくり活動における 行動変容に寄与する要因についての検討}

\author{
三沢登美子1、田畑 正司 ${ }^{2}$ 、長瀬 博文 ${ }^{3}$ 、城戸 照彦 ${ }^{4}$ \\ ${ }^{1} \mathrm{JFE}$ マテリアル、2 財団法人 石川県予防医学協会、3富山県衛生研究所、 ${ }^{4}$ 金沢大学医学部保健学科
}

【目的】平成 5 年度より「マイヘルス活動」という 自己宣言型の健康づくり活動を会社をあげて行 い、この活動が 10 年経過した。開始当初の 5 年間 の効果については一昨年の本学会で発表した。今 回は、この活動に参加した人のあげた目標が現在 も継続し、行動変容につながっている要因につい て検討することを目的とした。【対象及び方法】対 象は平成 5 年から平成 9 年の 5 年間に、富山県の ある鉄鋼業の従業員で、この健康づくり活動に参 加した 252 名のうち、連絡の取れない 16 名を除い た 236 名とした。自記式質問紙法で現職者には事 前に調査票を配布し、秋季の健康診断時に未記入 䇢所の聞き取り調查を行った。離職者には調査票 を郵送し、回収した。有効回答者は 210 名(男性 170 名、女性 40 名)、回収率 $89.0 \%$ であった。現職・ 離職別にみると、現職者 115 名、離職者 95 名で あった。【結果】健康目標であげた目標が一つでも 継続している人は 112 名 $(53.3 \%) 、$ 目標に近い状態 で継続できている人は 62 名 $(29.5 \%) 、$ 途中活動を 中断した人は 36 名 $(17.2 \%)$ であった。性・年歯令階 級別による継続状況では、女性より男性の方に継 続している人が有意に多く、女性では中断者が多 かった。また年齢階級別でみると男性では年歯が 高くなればなるほど継続している人が多く、逆に 女性の高齢者は継続中の人が少なく中断者が多 かった。職場環境については、男女とも「話題性あ り」に有意な差がみられ、「話題性なし」と答えた 職場環境で中断者が多く見られた。「仲間の有無」
では差が見られなかった。健康づくりを継続して いる理由については、男性では「健康の自主管理の ため」が一番多く、次いで「体調がいいので」「こ のままではまずいので」「以前からやっていたの で」「日分が病気をしたので」の順であり、女性で は「健康の自主管理のため」「以前からやっていた ので」「け分が病気したので」等であった。男性の 中断した理由で一番多かったのは、「今は健康だか ら」「やってもうまくいかないので」「目標を変えた ので」「時間がないので」であり、女性で一番多かっ たのは「時間がないので」で、次いで「やってもう まくいかないので」「家事や育児に手がかかる」「目 標を変えたので」の順であった。この活動の継続要 因をみるために、目標が一つでも継続している人 は 112 名と途中活動を中断した人は 36 名で多重 ロジスティック回帰分析を実施した。継続性が有 意に高かった項目は、「男性」(オッズ比 5.3)、「現 病歴がある人」（同 2.6）、「職場で話題性がある」 (3.4）であり、また、参加時の「ブレスローの点数 の低い (0-2 点) 人」に対し、「ブレスローの点数 が 3-4 点の人」(10.7)、「ブレスローの点数が 5-7 点 の人」(9.9) と有意に継続性の高いことが示された。 【まとめ】健康づくりの継続要因として、「男性」「現 病歴あり」「話題性あり」が継続性につながり、ま た、ブレスローの点数では低得点の人が継続しに くいことが分かった。今後はこれらの要因を考慮 して健康づくり活動を継続し、より効果のあるも のにしていくことが課題である。 